\title{
The role of PI3Ko isoform in cardioprotection
}

\author{
Xavier Rossello ${ }^{1}$ Jaime A. Riquelme $\mathrm{J}^{1,2} \cdot$ Zhenhe $\mathrm{He}^{1} \cdot$ Stasa Taferner $^{1}$. \\ Bart Vanhaesebroeck $^{3} \cdot$ Sean M. Davidson ${ }^{1} \cdot$ Derek M. Yellon $^{1}$
}

Received: 6 September 2017 / Accepted: 12 October 2017 / Published online: 17 October 2017

(c) The Author(s) 2017. This article is an open access publication

\begin{abstract}
Ischemic preconditioning (IPC) limits myocardial infarct size through the activation of the PI3K-Akt signal cascade; however, little is known about the roles of individual PI3K isoforms in cardioprotection. We aimed, therefore, to elucidate the role of the PI $3 \mathrm{~K} \alpha$ isoform in cardioprotection Pharmacological PI3K $\alpha$ inhibition was assessed in isolated-perfused mouse hearts subjected to ischemia/reperfusion injury (IRI), either during the IPC procedure or at reperfusion. PI3K $\alpha$ inhibition abrogated the IPC-induced protective effect at reperfusion, but not when given only during the IPC protocol. These results were confirmed in an in vivo model. Moreover, pharmacological $\mathrm{PI} 3 \mathrm{~K} \alpha$ activation by insulin at reperfusion was sufficient to confer cardioprotection against IRI. In addition, PI3K $\alpha$ was shown to be expressed and activated in mouse cardiomyocytes, mouse cardiac endothelial cells, as well as in mouse and human heart tissue. Furthermore, PI3K $\alpha$ was shown to mediate its effect though the inhibition of mitochondrial permeability transition pore opening. In conclusion, PI3K $\alpha$ activity is
\end{abstract}

Sean M. Davidson and Derek M. Yellon are joint senior coauthors.

Electronic supplementary material The online version of this article (doi:10.1007/s00395-017-0657-7) contains supplementary material, which is available to authorized users.

Derek M. Yellon

d.yellon@ucl.ac.uk

1 The Hatter Cardiovascular Institute, University College London, 67 Chenies Mews, London WC1E 6HX, UK

2 Advanced Center for Chronic Diseases (ACCDiS), Facultad de Ciencias Quimicas y Farmaceuticas and Facultad de Medicina, Universidad de Chile, Santiago, Chile

3 UCL Cancer Institute, University College London, London, UK required during the early reperfusion phase to reduce myocardial infarct size. This suggests that strategies specifically enhancing the $\alpha$ isoform of PI3K at reperfusion promote tissue salvage and as such, and could provide a direct target for clinical treatment of IRI.

Keywords Cardioprotection - Phosphoinositide 3-kinase · Ischemic preconditioning · Ischemia/reperfusion injury

$\begin{array}{ll}\text { Abbreviations } \\ \text { GPCR } & \text { G protein-coupled receptor } \\ \text { IPC } & \text { Ischemic preconditioning } \\ \text { IRI } & \text { Ischemia/reperfusion injury } \\ \text { IS } & \text { Infarct size } \\ \text { MCEC } & \text { Mouse cardiac endothelial cell } \\ \text { mPTP } & \text { Mitochondrial permeability transition pore } \\ \text { RISK } & \text { Reperfusion injury salvage kinase } \\ \text { ROS } & \text { Reactive oxygen species }\end{array}$

\section{Introduction}

Ischemic preconditioning (IPC), whereby brief cycles of non-lethal ischemia and reperfusion protect the myocardium from a subsequent, sustained ischemic insult, was first described by Murry et al. in a canine model in 1986 [35]. Over the last three decades, IPC has been reproduced in all species examined [54], including humans [53], and has also been replicated in other organs when applied either locally or remotely [18]. The underlying mechanisms of IPC have been largely uncovered and subsequently extrapolated to most cardioprotective therapies [13]. IPC has indeed become the paradigm for cardioprotection, although its signalling architecture is still the subject of intense research aimed to 
identify novel therapeutic targets to treat ischemia/reperfusion injury (IRI).

IPC signal transduction is understood to be mediated by a three-step process [16]: (1) the release of triggers that usually bind sarcolemmal membrane receptors (e.g., bradykinin); (2) the activation of intracellular mediators (signalling cascades that help initiate and propagate the signal, i.e., pro-survival kinases); and (3) the action of an end-effector that attenuates cell injury, i.e., inhibition of mitochondrial permeability transition pore (mPTP).

The IPC-induced protective effect is mediated by prosurvival signalling cascades, such as the Reperfusion Injury Salvage Kinase (RISK) pathway, the Survivor Activator Factor Enhancement (SAFE), and the NO/PKG pathway [9, 16, $26,29]$. The RISK pathway encompasses the activation of two parallel kinases (PI3K and ERK1/2) [14, 54]. PI3K has been demonstrated to play a dominant role within the RISK pathway [12, 40], with insights into its role in mediating IPC protection having been revealed by the use of pan-specific PI3K inhibitors, such as wortmannin and LY294002 [13]. In recent years, isoform-specific PI3K inhibitors have been developed in the field of oncology [51], but these have not yet been explored in the context of myocardial infarction, studies which could aid in the development of PI3K isoformspecific agents thereby further enhancing cardioprotection.

$\mathrm{PI} 3 \mathrm{~K} \alpha$ has emerged as a key player in cardiac physiology, improving contractility $[30,52]$, and promoting physiological exercise-induced growth, but not pathological hypertrophy [33]. Constitutively active PI3K $\alpha$ has also been demonstrated to improve left ventricular function in a heart failure model [28]. Using broad-spectrum PI3K inhibitors, insulin has proven to be cardioprotective through the activation of PI3K [22]. Based on the notion that insulin has been shown to be a canonical activator of $\mathrm{PI} 3 \mathrm{~K} \alpha[8,27]$, we hypothesized that $\mathrm{PI} 3 \mathrm{~K} \alpha$ may play a central role in cardioprotection. We, therefore, studied the importance of PI3K $\alpha$ either using PI3K $\alpha$-selective inhibitors and/or enhancing $\mathrm{PI} 3 \mathrm{~K} \alpha$ activity using insulin, or by delaying the opening of its endeffector mPTP through PI3K $\alpha$ inhibition. The dissection of this signalling pathway could help develop co-adjuvant interventions which, when added to reperfusion therapy, would further protect the heart against myocardial IRI in patients with an acute myocardial infarction.

\section{Methods}

\section{Animals and chemicals}

Animals used were male C57BL/6 mice (9-12 weeks, 24-28 g weight), obtained pathogen free from a single supplier and housed under identical conditions.
BYL719 (Alpelisib) was purchased from Selleck Chemicals. GDC-G326 was obtained from Genentech. Human insulin solution was purchased from Sigma-Aldrich. Dimethyl sulfoxide (DMSO, BDH laboratory supplies, UK) was used as the solvent for BYL719 and GDC-G326 at a final concentration not higher than $0.01 \%$.

Both GDC-G326 and BYL719 are potent and highly selective PI3K $\alpha$ inhibitors [5, 15, 48]; their dosage being established based on the previous publications [5, 48] and in a dose-response characterization study in this paper (see "Results" section). Insulin was tested as a canonical activator of PI3K $\alpha[8,27]$ and used at two doses: $100 \mathrm{mU} / \mathrm{mL}$ to characterize PI3K $\alpha$ inhibitors and $5 \mathrm{mU} / \mathrm{mL}$ as a low dose with known cardioprotective properties [1, 23].

\section{Experimental design and study protocols}

Outlines for most study protocols can be found through the figures, as well as in the supplemental material (Supplemental Figures 1-5). Additional protocols were as follows:

1. $P I 3 K \alpha$ protein levels aimed to characterize and quantify the expression under basal conditions of this PI3K isoform in both primary adult mouse cardiomyocytes and mouse cardiac endothelial cells (MCECs), as well as in mouse and human heart tissue ( $n=5$ per group).

2. IPC protocol selection Langendorff-perfused adult mice hearts were randomized into three groups (control, IPC 1 cycle, and IPC 4 cycles) to determine differences in myocardial infarct size and Akt activation.

3. PI3K $\alpha$ inhibitor dose selection aimed to determine the dose of PI3K $\alpha$ inhibitors against the canonical activator $\mathrm{PI} 3 \mathrm{~K} \alpha$ insulin, using Akt as a surrogate for PI3K activation and inhibition in line with published data [21, 31, 32, 50].

4. PI3K $\alpha$ inhibition to abolish the IPC-induced cardioprotective effect (ex vivo) aimed to determine the role of $\mathrm{PI} 3 \mathrm{~K} \alpha$ as IPC mediator in the ex vivo Langendorff-perfused mouse model, where hearts subjected to $35 \mathrm{~min}$ ischemia and $2 \mathrm{~h}$ reperfusion [39] received either GDCG326 or BYL719 during the IPC protocol (which consisted of 4 cycles of $5 \mathrm{~min}$ ischemia and $5 \mathrm{~min}$ reperfusion), or at reperfusion. Both myocardial infarct size and Akt phosphorylation were assessed separately for each set of experiments.

5. PI3K $\alpha$ inhibition to block the IPC-induced cardioprotective effect (in vivo) We used an in vivo mouse model of myocardial infarction (40 min ischemia and $120 \mathrm{~min}$ reperfusion) subjected to an IPC protocol, in the presence or absence of the PI3K $\alpha$ inhibitor GDC-G326, administered through external jugular vein at reperfusion. 
6. PI3K $\alpha$ activation at reperfusion (ex vivo) aimed to assess whether the administration of the PI3K $\alpha$ canonical activator (insulin) is sufficient to elicit cardioprotection and whether this effect can be abolished through $\mathrm{PI} 3 \mathrm{~K} \alpha$ inhibition. Both myocardial infarct size and Akt phosphorylation were evaluated.

7. PI3K $\alpha$ activation in cardiomyocytes and MCECs aimed to study whether both cell types could potentially be involved in the activation of the PI $3 \mathrm{~K} \alpha$ pathway (Akt phosphorylation was evaluated).

8. $P I 3 K \alpha$ translational ability aimed to evaluate whether $\mathrm{PI} 3 \mathrm{~K} \alpha$ activation, through its canonical activator in human tissue, can be comparable to the outcome observed in mouse tissue (Akt phosphorylation was evaluated).

9. Impact of PI3K $\alpha$ activation on the end-effector mPTP, aimed to evaluate whether $\mathrm{PI} 3 \mathrm{~K} \alpha$ activation delays mPTP opening (hence delaying cell death) using insulin as a canonical PI3K $\alpha$ activator and the GDC-G326 inhibitor. The outcome was measured as half time to mPTP opening.

\section{Ex vivo isolated Langendorff-perfused mouse heart model of acute myocardial infarction}

Heart isolation and Langendorff perfusion were carried out with filtered modified Krebs-Henseleit buffer (composed of $118 \mathrm{mM} \mathrm{NaCl}, 25 \mathrm{mM} \mathrm{NaHCO}, 11 \mathrm{mM}$ glucose, $4.7 \mathrm{mM}$ $\mathrm{KCl}, 1.22 \mathrm{mM} \mathrm{MgSO} \cdot 7 \mathrm{H}_{2} \mathrm{O}, 1.21 \mathrm{mM} \mathrm{KH}_{2} \mathrm{PO}_{4}$, and $\left.1.84 \mathrm{mM} \mathrm{CaCl} \cdot 2 \mathrm{H}_{2} \mathrm{O}\right)$ aerated with a mixture of $\mathrm{O}_{2}(95 \%)$ and $\mathrm{CO}_{2}(5 \%)$ to uphold $\mathrm{pH}$ at $7.40 \pm 0.3$, as previously described [39]. Briefly, mice were given terminal anesthesia and anticoagulation through an intraperitoneal injection of $60 \mathrm{mg} / \mathrm{kg}$ sodium pentobarbitone and $100 \mathrm{IU}$ heparin, respectively. Hearts were then harvested, submerged in icecold modified Krebs-Henseleit buffer, and immediately cannulated with a 21-gauge cannula to be retrogradely perfused on a murine Langendorff perfusion apparatus at $80 \mathrm{~mm} \mathrm{Hg}$ pressure.

Predefined exclusion criteria were as follows: (1) more than 4 min time between heart removal and the start of perfusion in the Langendorff mode; (2) temperature above or below the $37+0.5{ }^{\circ} \mathrm{C}$ range; and (3) buffer flow rate of the isolated heart of less than $1 \mathrm{~mL} / \mathrm{min}$ or more than $6.5 \mathrm{~mL} /$ min on the Langendorff preparation during the stabilization period. After evaluating for exclusion criteria in an initial 20 min stabilization period, the hearts were subjected to experimental protocols of: (a) perfusion for $30 \mathrm{~min}$ to collect heart tissue and study the protein expression of PI $3 \mathrm{~K} \alpha$ under basal conditions; (b) IRI in the presence of IPC, drug, and/or vehicle, as indicated in each protocol (see Fig. 3a, c; Supplemental Figures 1 and 4); and (c) Akt phosphorylation following a given intervention, such as IPC and/or PI3K $\alpha$ activation and inhibition (see Fig. 4a; Supplemental Figures 2, 3, and 5).

\section{In vivo murine model of acute myocardial infarction}

C57Bl/6 mice were anaesthetized by intraperitoneal injection of $80 \mathrm{mg} / \mathrm{kg}$ pentobarbitone at a concentration of $20 \mathrm{mg} /$ $\mathrm{mL}$ in $0.9 \%(\mathrm{w} / \mathrm{v})$ saline and maintained at $36.5 \pm 0.5^{\circ} \mathrm{C}$ on a heating mat. Surgery was started after confirming the abolishment of pedal and tail reflexes. Mice were intubated using a 19G cannula and ventilated with room air using a MiniVent, type 845, Small Animal Ventilator (Harvard Apparatus, Kent, UK), at a flow rate of $1.0 \mathrm{l} / \mathrm{min}$ with $2 \mathrm{cmH}_{2} \mathrm{O}$ PEEP, stroke volume $200 \mu \mathrm{l}$ at 130 strokes/min. All mice were subjected to occlusion of the left anterior descending (LAD) for $40 \mathrm{~min}$, which was verified by ST elevation in the electrocardiogram and by the presence of hypokinesia and pallor in the heart, followed by $2 \mathrm{~h}$ reperfusion. After the protocol finished, animals were killed by exsanguination via the thoracic aorta. Afterwards, myocardial IS was measured as described in the next section. A total of 33 mice were used for infarct experiments and were randomly assigned to treatment group. Seven mice died during the procedure and were, therefore, excluded from analyses (three in control group, three in IPC, and one in IPC + GDC-G326); hence, each group included six animals.

Mice were randomized to the following groups: (1) control; (2) IPC; (3) IPC and GDC-G326 at reperfusion; and (4) GDC-G326 at reperfusion (see Fig. 3d for further details). IPC was induced by applying 3 cycles of $5 \mathrm{~min}$ ischemia and 5 min reperfusion in the LAD. Vehicle control and IPC mice received $50 \mu \mathrm{l}$ of $6 \%$ DMSO in saline (vehicle). GDC-G326 was dissolved in DMSO and injected via external jugular vein (6 $\mu \mathrm{g}$ per $\sim 25 \mathrm{~g}$ mouse) at reperfusion in groups 3 and 4.

\section{Myocardial infarct size analysis}

At the end of the protocol, the heart was either removed from the Langendorff rig (ex vivo experiments) or else isolated from the animal and aortic root cannulated (in vivo experiments, and $5 \mathrm{~mL}$ of $1 \%$ 2,3,5-triphenyltetrazolium chloride (TTC) in phosphate-buffered saline injected through the aortic cannula and incubated for $10 \mathrm{~min}$ at $37^{\circ} \mathrm{C}$ to demarcate the infarcted (white) vs. viable (red) tissue [25]. For regional IRI experiments, the LAD coronary artery was then re-ligated to perfuse Evans blue dye ( $2 \mathrm{~mL}$ of $0.5 \%$ ) to delineate the area at risk (AAR).

After the incubation, hearts were frozen overnight at $-20{ }^{\circ} \mathrm{C}$ and sectioned perpendicular to the long axis the day after, being the slices transferred into $10 \%$ neutral formalin buffer for $1 \mathrm{~h}$ at room temperature. Images were taken and coded to blind the analyzer. Planimetry analysis using Image 
J version 1.47 (NIH, Bethesda, MD, USA) was carried out to quantify myocardial IS as a percentage of the AAR.

\section{Human atrial tissue acquirement}

Human atrial tissues were collected from Barts Heart Centre at St Bartholomew's Hospital. The study received Local Research Ethics Committee approval (REC No. 00/0275) and was carried out in accordance with the University College London Hospitals NHS Trust guidelines. All patients were provided with a Patient Information Sheet and a verbal explanation of the study, in line with Good Clinical Practice guidelines. All patients provided written informed consent and were free to participate in the Barts Cardiovascular Registry.

All patients were aged $18-80$ years and their baseline characteristics were recorded upon consent. Patients with impaired renal or ventricular function, dilated left atria, or a history of arrhythmias or on rhythm stabilising medications were excluded. Patients with arrhythmias were excluded based on a previous publication demonstrating that PI3K activation in atrial appendages from patients with atrial fibrillation was lower compared with tissue from patients in sinus rhythm [37].

Right atrial appendage samples were harvested from patients undergoing cannulation for cardiopulmonary bypass either for coronary artery bypass graft or valve replacement. Once the cardiac surgeon provided the atrial tissue, samples were placed in ice-cold, oxygenated modified Tyrode's buffer ( $\mathrm{NaCl} 118.5 \mathrm{mM}, \mathrm{KCL} 4.8 \mathrm{mM}, \mathrm{NaHCO}_{3} 24.8 \mathrm{mM}$, $\mathrm{KH}_{2} \mathrm{PO}_{4} 1.2 \mathrm{mM}, \mathrm{MgSO}_{4} \cdot 7 \mathrm{H}_{2} \mathrm{O} 1.44 \mathrm{mM}, \mathrm{CaCl}_{2} \cdot 2 \mathrm{H}_{2} \mathrm{O}$ $1.8 \mathrm{mM}$, glucose $10.0 \mathrm{mM}$, pyruvic acid $10 \mathrm{mM}, \mathrm{pH} 7.4$ ) and transferred promptly to The Hatter Cardiovascular Institute at University College London.

Right atrial appendage samples were used for both assessing the basal protein expression of PI $3 \mathrm{~K} \alpha$ and undertaking a pharmacologic approach with both PI $3 \mathrm{~K} \alpha$ activator and inhibitor.

\section{Experimental protocol for adult mouse ventricular cardiomyocyte isolation}

Adult mouse ventricular cardiomyocytes were isolated using liberase heart digestion as described previously [38]. Briefly, hearts were excised and cannulated through the aorta before retrograde perfusion on a murine Langendorff apparatus at $37^{\circ} \mathrm{C}$. Following perfusion with buffer (consisted of $\mathrm{NaCl}$ $113 \mathrm{mM}, \mathrm{KCl} 4.7 \mathrm{mM}, \mathrm{KH} 2 \mathrm{PO}_{4} 0.6 \mathrm{mM}, \mathrm{Na}_{2} \mathrm{HPO}_{4} 0.6 \mathrm{mM}$, $\mathrm{MgSO}_{4} \cdot 7 \mathrm{H}_{2} \mathrm{O} 1.2 \mathrm{mM}, \mathrm{NaHCO}_{3} 12 \mathrm{mM}, \mathrm{KHCO}_{3} 10 \mathrm{mM}$, Hepes Na salt $0.922 \mathrm{mM}$, Taurine $30 \mathrm{mM}$, 2,3-butanedionemonoxime $10 \mathrm{mM}$ and glucose $5.5 \mathrm{mM}$ ) for 5 min to clear residual blood, and enzymatic digestion was performed using $30 \mathrm{~mL}$ perfusion buffer with $5 \mathrm{mg}$ Liberase (Roche,
UK) and $12.5 \mu \mathrm{mol} / \mathrm{L} \mathrm{CaCl}_{2}$ for about $20 \mathrm{~min}$. At the end of enzymatic digestion, both ventricles were isolated and mechanically disaggregated in a gentle manner. The resulting cell suspension was filtered through a mesh and transferred for enzymatic inactivation to a tube with $10 \mathrm{~mL}$ of stopping buffer (perfusion buffer supplemented with fetal bovine serum $10 \%$ ), and $\mathrm{Ca}^{2+}$ was gradually re-introduced with a three-step increasing $\mathrm{CaCl}_{2}$ concentration. Cells were then re-suspended in M199 (Invitrogen, UK) supplemented with L-carnitine $(2 \mathrm{mM})$, creatine $(5 \mathrm{mM})$, taurine $(5 \mathrm{mM})$, penicillin $(100 \mathrm{IU} / \mathrm{mL})$, streptomycin $(100 \mathrm{IU} / \mathrm{mL})$, and $25 \mu \mathrm{mol} / \mathrm{L}$ blebbistatin.

\section{Cell culture}

Immortalized mouse cardiac endothelial cell (MCEC) is derived from microvascular neonatal mouse cardiac endothelial cells.

MCECs were cultured with Dulbecco's modified eagle medium (DMEM) supplemented with $10 \%$ fetal bovine serum at $80-90 \%$ confluence. The cells were kept in an incubator at $37{ }^{\circ} \mathrm{C}$, with $95 \% \mathrm{O}_{2}$ and $5 \% \mathrm{CO}_{2}$.

MCECs were used to quantify the protein levels of PI $3 \mathrm{~K} \alpha$ as well as to study their response to the pharmacological activation and inhibition of PI3K $\alpha$.

\section{Tissue homogenates}

Mouse hearts and human atrial tissues were obtained as previously described. Tissue samples were swiftly snapfrozen in liquid nitrogen after being collected and then stored at $-80^{\circ} \mathrm{C}$ until further processing. The tissue was homogenized in protein lysis buffer, containing Tris $\mathrm{pH}$ $6.8(100 \mathrm{nM}), \mathrm{NaCl}(300 \mathrm{mM}), \mathrm{NP} 400.5 \%$, Halt protease inhibitor cocktail, Halt phosphatase inhibitor cocktail, and 0.5 M EDTA (all from Thermo Scientific, UK) and adjusted to $\mathrm{pH}$ 7.4. Homogenates were then sonicated before being centrifuged at $4{ }^{\circ} \mathrm{C}$ to remove the pellet containing debris and DNA.

\section{Western blot analyses}

To ensure equal sample loading, protein concentration was determined using bicinchoninic acid (BCA) protein assay reagent (Sigma, UK) and adjusted accordingly. NuPAGE LDS Sample Buffer (4X) (Thermofisher Scientific, UK) plus $5 \% \beta$-mercaptoethanol were added to the samples, which were subsequently denatured by heating to $100{ }^{\circ} \mathrm{C}$ for $10 \mathrm{~min}$. Samples were then loaded on NuPAGE Novex $10 \%$ Bis-Tris protein gels (Thermofisher scientific, UK) using the Mini Protean III system (Bio-Rad, UK). Proteins were transferred onto nitrocellulose blotting membrane (GE Healthcare Life Sciences, UK) through wet transfer in 
a Bio-Rad Mini Trans-Blot. The membranes were blocked for $1 \mathrm{~h}$ using $5 \%$ bovine serum albumin/PBS tween and subsequently incubated with appropriate primary antibodies at $4{ }^{\circ} \mathrm{C}$ overnight.

The following primary antibodies being used were acquired from Cell Signalling Technology: Akt (\#9272), Phospho-Akt (Ser473) (\#9271), Phospho-Akt (Thr308) (\#2965), and PI3 Kinase p110 $\alpha$ (\#4249). Anti-GAPDH (mAbcam, \#9484) was used as loading control. After overnight incubation, membranes were probed with secondary antibodies. Levels of protein were finally quantified using the Odyssey imaging system from Li-Cor Biosciences (Image Studio Lite Ver 5.2).

\section{Basal PI3K $\alpha$ protein expression}

Expression of PI3K $\alpha$ protein levels was evaluated by western blot analyses in mouse heart and human atrial tissues, as well as primary adult ventricular mouse cardiomyocytes and MCECs line.

To quantify protein expression, three different amounts of recombinant $\mathrm{PI} 3 \mathrm{~K} \alpha$ protein $(1,3$, and $10 \mathrm{ng}, \mathrm{PI} 3 \mathrm{~K} \alpha$ from Merck Millipore) were loaded in the gels alongside the samples of interest. After being transferred, membranes were probed with specific primary antibodies for $\mathrm{PI} 3 \mathrm{~K} \alpha$. For each membrane, PI3K $\alpha$ values were extrapolated using a lineal regression. Results were expressed as ng of PI3K $\alpha$ per $\mu \mathrm{g}$ of heart protein.

\section{Basal PI3K $\alpha$ mRNA expression}

Mouse hearts were removed and perfused with PBS to remove the blood and then formalin-fixed, paraffin-embedded, and sectioned.

RNAscope (ACD Bio) was performed according to the manufacturer's methods. Briefly, slides were deparaffinised for $10 \mathrm{~min}$ in Histoclear and then dried in $100 \%$ alcohol. Slides were incubated in hydrogen peroxide for $10 \mathrm{~min}$ RT, and then washed in distilled water. Antigen retrieval was performed by heating for $15 \mathrm{~min}$ at $100{ }^{\circ} \mathrm{C}$ in target retrieval reagent, then incubating for $30 \mathrm{~min}$ at $40^{\circ} \mathrm{C}$ in protease plus. Next, the tissue section was hybridized with the RNAscope ${ }^{\circledR}$ Mm-Pik3ca Probe (catalogue number 313581), for $2 \mathrm{~h}$ at $40{ }^{\circ} \mathrm{C}$, washed, and fluorescence developed using the Perkin Elmer TSA plus fluorescein kit. The slides were then counterstained with DAPI to stain nuclei, mounted overnight, and sequentially imaged using the $405 \mathrm{~nm}$ (for DAPI) and $488 \mathrm{~nm}$ laser lines of a Leica confocal microscope and emission filters of 410-480 and 495-550 nm. Positive control slides using the positive control probes supplied in the kit, and negative controls in the absence of hybridization probe were performed in parallel.

\section{Pharmacologic activation and inhibition of PI3K $\alpha$ in cells and tissues}

Akt phosphorylation was evaluated by western blot analyses after the pharmacologic activation and inhibition of $\mathrm{PI} 3 \mathrm{~K} \alpha$ in tissues (mouse heart and human atrial tissues) and cells (primary adult ventricular mouse cardiomyocytes and MCECs).

Prior to being subjected to the pharmacologic stimulation, MCECs were deprived of serum for $2 \mathrm{~h}$. Both cell types were incubated for $15 \mathrm{~min}$ according to the following interventions: (1) vehicle control (0.01\% DMSO); (2) Insulin ( $5 \mathrm{mUl} / \mathrm{mL})$; (3) Insulin $5 \mathrm{mUl} / \mathrm{mL}$ with $30 \mathrm{~min}$ pretreatment GDC-G326 $3 \mu \mathrm{M}$; and (4) GDC-G326 $3 \mu \mathrm{M}$.

Mouse Langendorff-perfused hearts were stabilized for $20 \mathrm{~min}$ and then perfused for $15 \mathrm{~min}$ with: (1) vehicle control (DMSO) perfusion; (2) Insulin ( $5 \mathrm{mUl} / \mathrm{mL})$; (3) Insulin $5 \mathrm{mUl} / \mathrm{mL}$ and GDC-G326 $3 \mu \mathrm{M}$; and (4) GDC-G326 $3 \mu \mathrm{M}$.

After being collected in the theatre, human atrial tissue was dissected in four pieces and swiftly submerged in previously oxygenated Tyrode's modified buffer $(\mathrm{NaCl}$ $118.5 \mathrm{mM}, \mathrm{KCL} 4.8 \mathrm{mM}, \mathrm{NaHCO}_{3} 24.8 \mathrm{mM}, \mathrm{KH}_{2} \mathrm{PO}_{4}$ $1.2 \mathrm{mM}, \mathrm{MgSO}_{4} \cdot 7 \mathrm{H}_{2} \mathrm{O} 1.44 \mathrm{mM}, \mathrm{CaCl}_{2} \cdot 2 \mathrm{H}_{2} \mathrm{O} 1.8 \mathrm{mM}$, glucose $10.0 \mathrm{mM}$, pyruvic acid $10 \mathrm{mM}$, pH 7.4) for $30 \mathrm{~min}$ in the presence of: (1) vehicle control (DMSO); (2) Insulin (5 $\mathrm{mUl} / \mathrm{mL}$ ); (3) Insulin $5 \mathrm{mUl} / \mathrm{mL}$ and GDC-G326 $3 \mu \mathrm{M}$; and (4) GDC-G326 $3 \mu \mathrm{M}$. Of note, the tissue was not perfused, but superfused and under ongoing hypoxia whilst being transferred to the laboratory.

\section{mPTP opening assay}

The sensitivity of the mPTP to opening was assayed using a well-characterized cellular model of reactive oxygen species (ROS)-mediated mPTP opening [6]. Briefly, tetra-methyl rhodamine methyl ester (TMRM, from S Sigma-Aldrich, UK), a lipophilic cation which is very positively charged, accumulates selectively into the negatively charged mitochondrial matrix. At high concentration (12 $\mu \mathrm{M})$, TMRM becomes quenched at the mitochondria. Constant confocal laser stimulation (at $543 \mathrm{~nm}$ wavelength) of TMRM generates ROS within the mitochondria thereby simulating mitochondrial ROS production during reperfusion. After a few minutes of continual confocal laser scanning, ROS induces mPTP opening, producing a drop in mitochondrial membrane potential and resulting in the dequenching of TMRM, which in turn relocates to the cytoplasm [7]. This leak of the dye from the mitochondria to the cytosol increases the detectable fluorescent signal, which is used as surrogate marker for mPTP opening.

Adult mouse ventricular cardiomyocytes were isolated as previously described. Live cardiomyocytes were incubated with the fluorescent dye TMRM at $12 \mu \mathrm{M}$ for $15 \mathrm{~min}$ in 
Hepes-based recording buffer $(\mathrm{NaCl} 156 \mathrm{mM}, \mathrm{KCl} 3 \mathrm{mM}$, $\mathrm{MgSO}_{4} .7 \mathrm{H}_{2} \mathrm{O} 2 \mathrm{mM}, \mathrm{K}_{2} \mathrm{HPO}_{4} 1.25 \mathrm{mM}, \mathrm{CaCl}_{2} 2 \mathrm{mM}$, HEPES $10 \mathrm{mM}$, and D-glucose $10 \mathrm{mM}$; pH 7.4), then washed and randomly treated for $15 \mathrm{~min}$ into the following groups: (1) vehicle control; (2) insulin $5 \mathrm{mU} / \mathrm{mL}$; (3) insulin $5 \mathrm{mU} /$ $\mathrm{mL}$ with GDC-G326 $3 \mu \mathrm{M}$; and (4) GDC-G326 $3 \mu \mathrm{M}$ alone. Once washed for a second time, mouse cardiomyocytes were stimulated with laser illumination and imaged using confocal microscopy. The time to reach half peak signal was recorded in seconds and compared across groups. A total of $19 \pm 2$ cardiomyocytes were analyzed for each intervention in each experiment ( $n=8$ mice).

\section{Statistical analyses}

Normal distribution of each data subset was tested using graphical methods and the Kolmogorov-Smirnov method. All values are presented as mean \pm standard error of the mean. Comparisons between protein content of PI3K $\alpha$ were performed using the unpaired $t$ test or the Mann-Whitney test depending on the normal distribution of the data. All other continuous data were compared either using one-way analysis of variance if normally distributed or using the nonparametric Kruskal-Wallis test if highly skewed distributed. $P$ values for post hoc pairwise comparisons to the control group were adjusted using the Dunnett's test if normally distributed or the Dunn's test if non-normally distributed. A $P$ value of less than 0.05 was considered statistically significant. STATA software version 13.1 (Stata Corp, College Station, TX, USA), SPSS Statistics version 21 (IBM, Armonk, NY, USA), and GraphPad Prism version 6.00 (GraphPad Software, La Jolla, CA, USA) were used to perform the analyses and produce the graphs. The results were reported according to the ARRIVE guidelines for reporting animal research [24].

\section{Results}

\section{PI3Ko expression levels in cardiac tissue and cells}

We first quantified PI3K $\alpha$ protein expression in mouse and human heart tissue relative to recombinant $\mathrm{PI} 3 \mathrm{~K} \alpha$ standards (Fig. 1a). In the tissue, PI3K $\alpha$ was found to be expressed at a similar level of total protein in both mouse and human heart, respectively $(0.20 \pm 0.03$ and $0.21 \pm 0.04 \mathrm{ng}$ per $\mu \mathrm{g}$ heart protein, $P=0.76)$. At a cellular level, PI3K $\alpha$ was 2.5 fold more highly expressed in endothelial cells than in cardiomyocytes (Fig. 1b). PI3K $\alpha$ mRNA expression in mouse cardiac tissue (Fig. 1c, d) also suggests a greater expression of this isoform in endothelial cells compared to cardiomyocytes.

\section{Selection of IPC protocol and PI3K $\alpha$ inhibitor dose}

To select an IPC protocol able to confer protection in an ex vivo model, we compared preconditioning strategies of 1 cycle vs. 4 cycles. IPC 4 cycles demonstrated a significant reduction of myocardial infarct size (IS) compared to control group $(21.1 \pm 3.2$ vs. $38.0 \pm 1.7 \%, P=0.006)$, whilst IPC 1 cycle was not effective $(34.3 \pm 4.6, P=0.67$ compared to control group) (Fig. 2a). PI3K pathway activation, as assessed by the levels of phospho-serine 473 and phosphothreonine 308 Akt levels, was increased after IPC 4 cycles compared to the control group, whilst Akt phosphorylation after IPC 1 cycle was not significantly increased (Fig. 2b-d).

To identify appropriate doses of PI $3 \mathrm{~K} \alpha$ inhibitors, we generated a dose-response curve using GDC-G326 and BYL719, two distinct PI3K $\alpha$-selective inhibitors, in the context of stimulation with insulin, a known canonical activator of PI3K $\alpha$. These experiments indicated that $3 \mu \mathrm{M}$ of each drug is sufficient to inhibit Akt(Ser473) and Akt(Thr308) phosphorylation induced by insulin (Fig. 2e-g). Hence, these concentrations were used to evaluate the role of PI3K $\alpha$ in cardioprotection in subsequent experiments.

\section{PI3Ko mediates protection by IPC against myocardial IRI}

In the Langendorff-perfused, ex vivo mouse heart model, IPC reduced IS compared to control (49 \pm 4 vs. $23 \pm 2 \%$, $P<0.001)$. This protection was unaffected by GDC-G326 $(26 \pm 3 \%)$ or BYL719 $(25 \pm 3 \%)$ when administered only during IPC, despite Akt phosphorylation being inhibited (Figs. 3a, b, 4b). Importantly, these two structurally distinct inhibitors did abrogate protection when given at reperfusion (GDC-G326: $50 \pm 3 \%$; BYL719: $47 \pm 4 \%$ ) and also blocked Akt phosphorylation (Figs. 3c, d, 4c), revealing a distinct role for the $\mathrm{PI} 3 \mathrm{~K} \alpha$ isoform during the early moments of reperfusion. Neither drug affected IS on its own.

These experiments were confirmed in an in vivo setting using GDC-G326, which was found to block IPC protection when administered at reperfusion (control $56 \pm 5$ vs. IPC + GDC-G326 $60 \pm 5 \%, P=0.93$, and IPC alone was $29 \pm 6 \%, P=0.003$ ) (Fig. 3e, f).

\section{Insulin, a canonical activator of PI3K $\alpha$, is protective at reperfusion}

Having established that $\mathrm{PI} 3 \mathrm{~K} \alpha$ is necessary to mediate the protection provided by preconditioning, we evaluated whether activation of $\mathrm{PI} 3 \mathrm{~K} \alpha$ at reperfusion would be sufficient to elicit a protective effect. When administered at reperfusion, the canonical $\mathrm{PI} 3 \mathrm{~K} \alpha$ activator (insulin) reduced myocardial IS compared to control $(25 \pm 2$ vs. $55 \pm 4 \%, P<0.001)$ and this protection was abolished by 
Fig. 1 PI $3 K \alpha$ protein and mRNA levels. PI3K $\alpha$ protein expression in mouse and human cardiac tissue (a) and cardiomyocytes and endothelial cells (b). PI $3 \mathrm{~K} \alpha$ values were extrapolated using a lineal regression from three different amounts of recombinant $\mathrm{PI} 3 \mathrm{~K} \alpha(1,3$, and $10 \mathrm{ng})$. Results are presented as mean \pm SEM and expressed as ng of $\mathrm{PI} 3 \mathrm{~K} \alpha$ per $\mu \mathrm{g}$ of heart protein. $\mathrm{PI} 3 \mathrm{~K} \alpha$ mRNA expression in mouse cardiac tissue (c, d, with and without DAPI-stained nuclei in blue, respectively). RNAScope, a high sensitivity method of in situ hybridization, was used to specifically detect PI3Kalpha mRNA expression in mouse heart sections. Bright dots represent PI3Kalpha mRNA. A few dots are visible in the cytosol of cardiomyocytes (visible from their green autofluorescent background), but there are proportionally many more dots in the endothelial cells of capillaries running alongside them, as indicated by arrow heads, and in endothelial cells lining larger vessels (demarcated by dotted lines). Scale bar $20 \mu \mathrm{m} . * P<0.05, * * P<0.01$, $* * * P<0.001$, and $n s$ nonsignificant
A

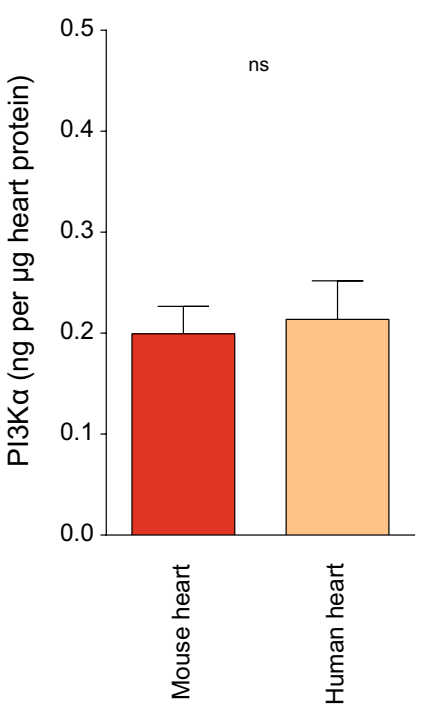

B

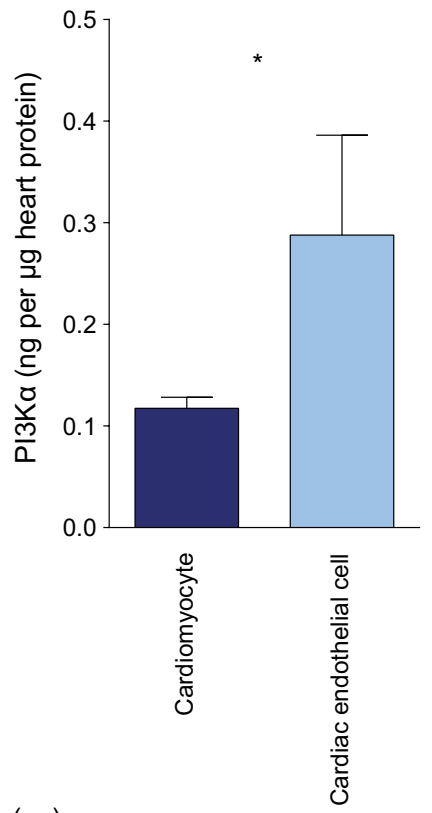

Pl3Ka purified protein $(\mathrm{ng})$

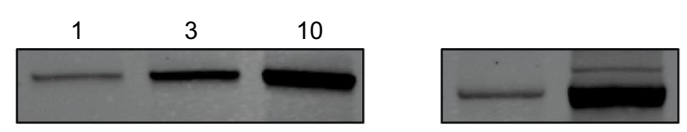

C

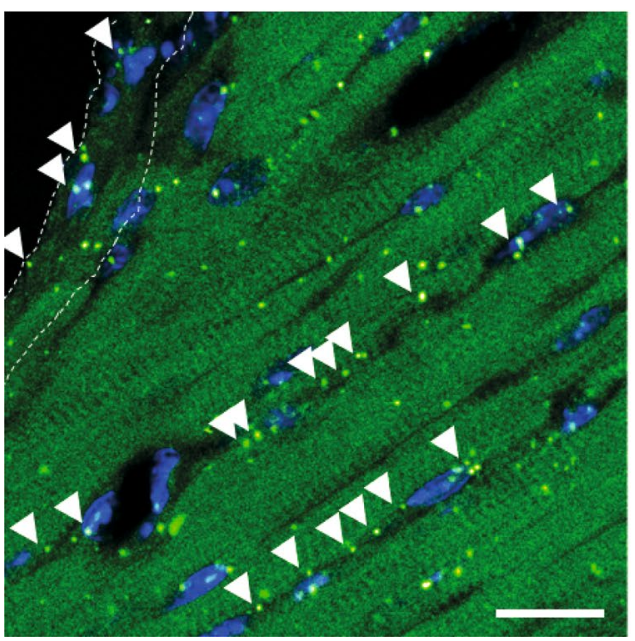

D

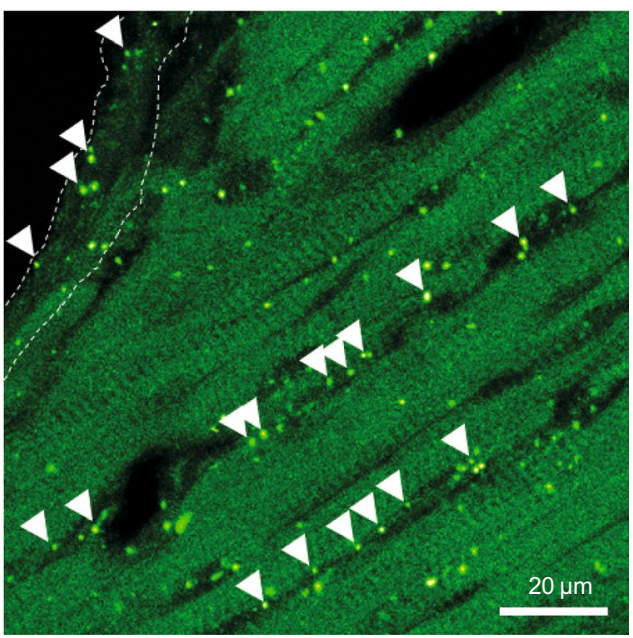

GDC-G326 (48 $\pm 3 \%, P=0.687$ compared to control), as depicted in Fig. 5a. The degree of protection was similar to that attained using bradykinin as a pharmacological positive control. Accordingly, Akt was activated by insulin and blocked when GDC-G326 was co-administered at reperfusion following a protocol of IRI (Fig. 5b-d).

\section{PI3K $\alpha$ can be activated in mouse cardiomyocytes, endothelial cells, and atrial human tissue}

Having established a central role of PI3K $\alpha$ in cardioprotection, we aimed to determine whether insulin stimulated
PI3K $\alpha$ activation only in cardiomyocytes or also cardiac endothelial cells. Our results show that Akt is activated in both cell types in response to insulin and this effect was lost upon co-administration with GDC-G326 (Fig. 6a, b). Furthermore, to assess the translation potential of our findings, we collected human right atrial appendage samples and tested whether the PI3K $\alpha$ pathway could be stimulated (patient baseline characteristics are outlined in Table 1). Human tissue was shown to respond to insulin with PI3K $\alpha$-dependent phosphorylation of Akt, although the fold increase was lower due to a higher basal activity (Fig. 6c, d). 


\section{IPC protocol selection}

A

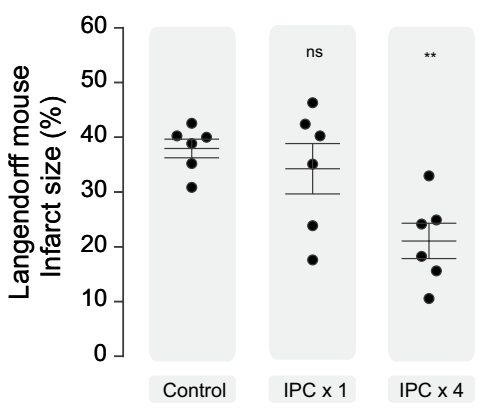

B

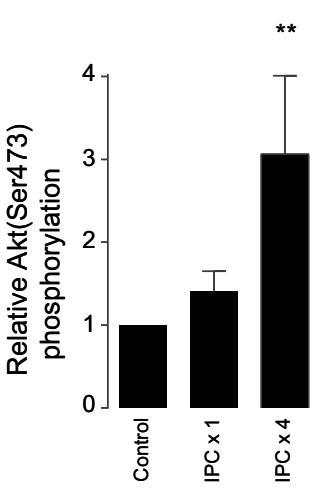

C

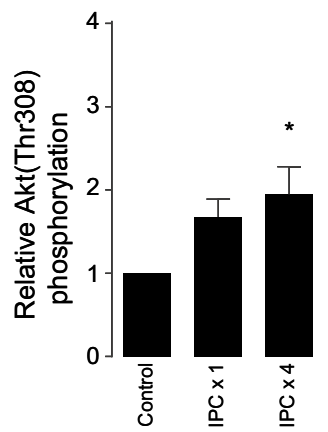

D

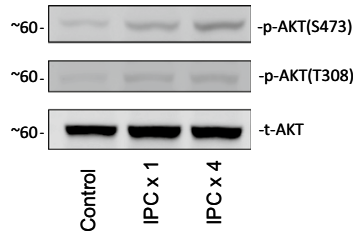

\section{PI3Ka inhibitors selection}

\section{$\mathbf{E}$}

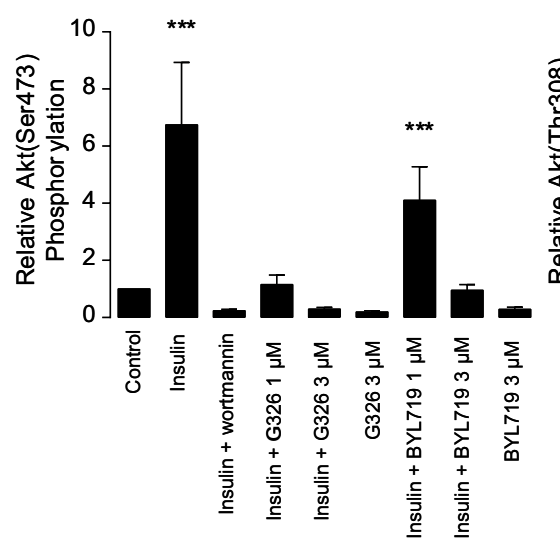

$\mathbf{F}$

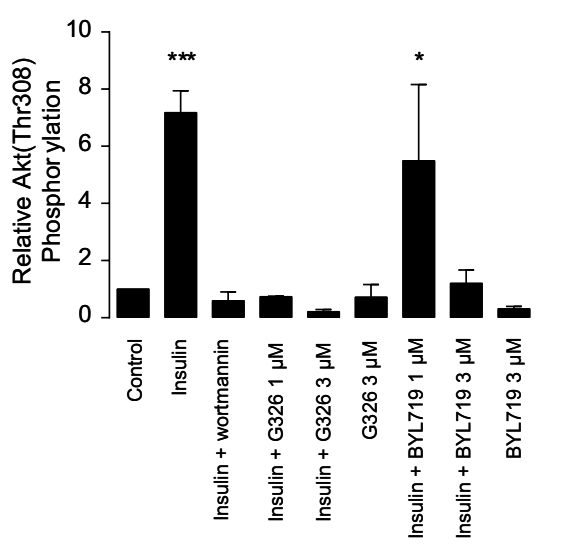

G

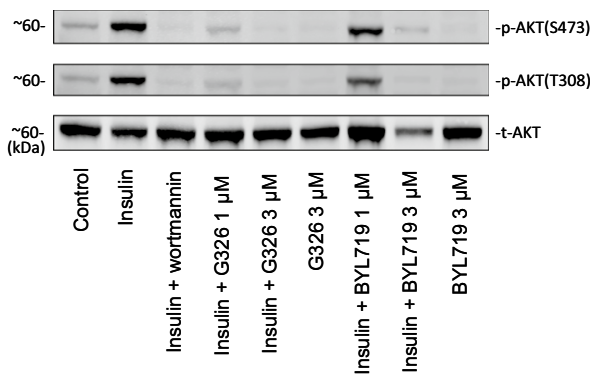

Fig. 2 IPC protocol and PI $3 \mathrm{~K} \alpha$ inhibitors dose selection. a Effect of two ischemic preconditioning (IPC) protocols on myocardial infarct size (\%). b-d Impact of IPC protocols on Akt phosphoryla- tion. e-g Dose-response curve of two PI3K $\alpha$ inhibitors (BYL719 and GDC-G326) when co-administered with the $\alpha$ canonical activator. $* P<0.05, * * P<0.01, * * * P<0.001$, and $n s$ non-significant

\section{PI3K $\alpha$ activation delays the mPTP opening}

The sensitivity of the mPTP to opening was assayed in adult mouse ventricular cardiomyocytes using a well-characterized cellular model of ROS-mediated mPTP opening. In the presence of insulin, the time taken to induce MPTP opening (a surrogate for cell death) was significantly increased compared to control $(571 \pm 30$ vs. $459 \pm 25, P<0.013)$, whilst treatment with GDC-G326 abrogated this effect $(455 \pm 24 \mathrm{~s}$, $P=0.999)$ (Fig. 6e), GDC-G326 having no effect on its own $(467 \pm 25 \mathrm{~s}, P=0.993)$. These results suggest that
PI3K $\alpha$ signalling promotes cardiomyocyte survival through the inhibition of the end-effector, mPTP.

\section{Discussion}

\section{Summary of findings}

Using a targeted pharmacological approach, we show that $\mathrm{PI} 3 \mathrm{~K} \alpha$ activity is required during the early reperfusion phase to reduce myocardial infarct size, as demonstrated with IPC in both ex vivo and in vivo myocardial infarction models. In 
PI3Ka inhibition during the IPC protocol phase (ex vivo model)

A

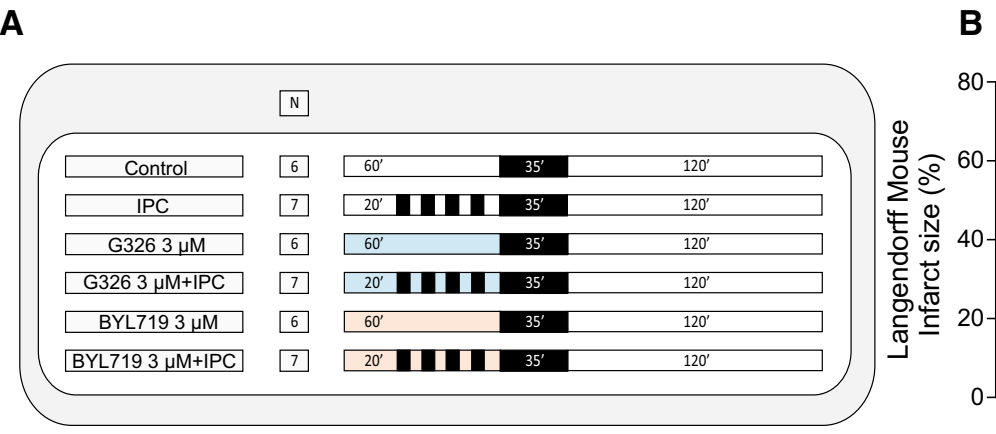

B
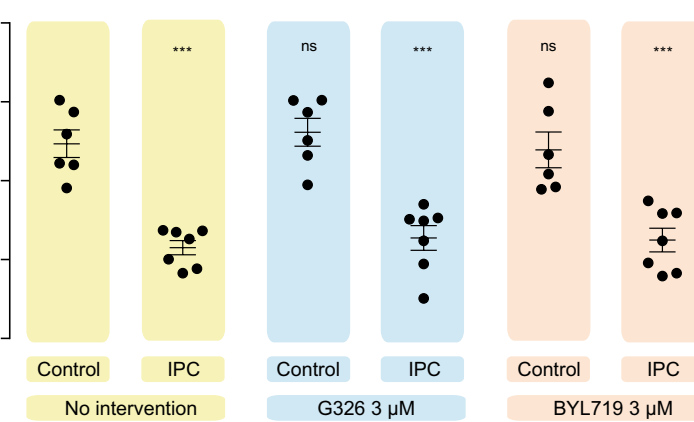

No intervention

G326 $3 \mu \mathrm{M}$

BYL719 $3 \mu \mathrm{M}$

\section{PI3Ka inhibition during reperfusion phase (ex vivo model)}

C

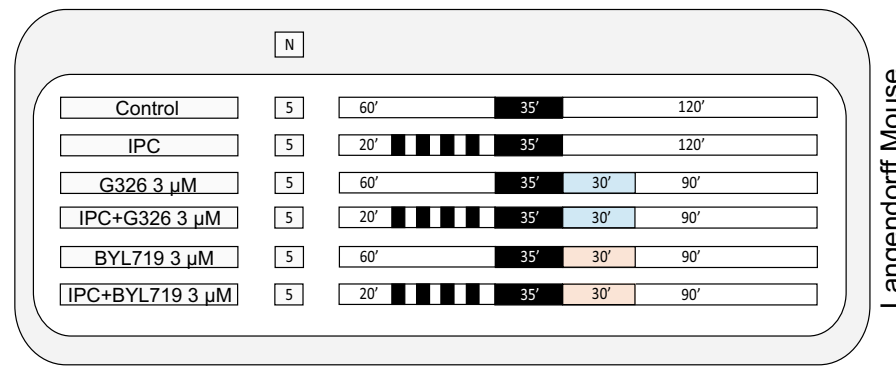

D

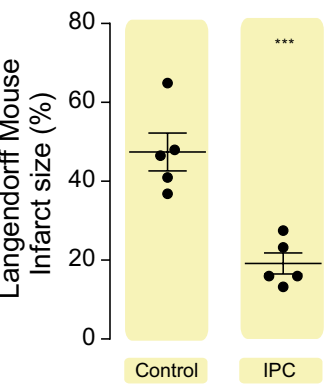

No intervention
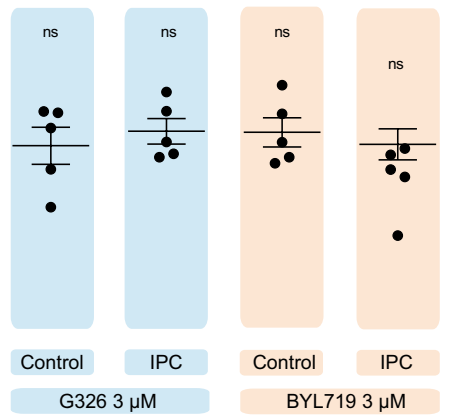

\section{PI3Ka inhibition during reperfusion phase (in vivo model)}

E

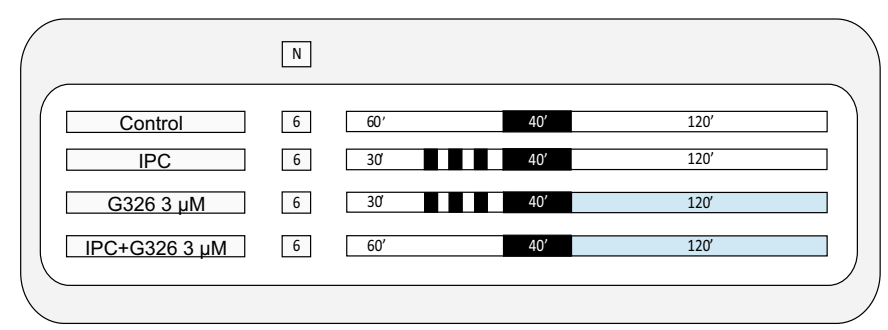

$\mathbf{F}$

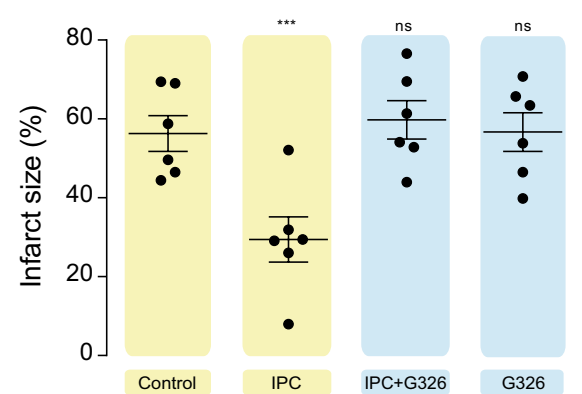

Fig. $3 \mathrm{PI} 3 \mathrm{~K} \alpha$ inhibition in ischemic preconditioning. Effect on myocardial infarct size of two PI3K $\alpha$ inhibitors (BYL719 and GDC-G326) when administered during the IPC protocol (a, b) or at reperfusion $(\mathbf{c}, \mathbf{d})$. The study protocol and results in the in vivo model are depicted in $\mathbf{e}$ and $\mathbf{f}$, respectively. $* P<0.05$, $* * P<0.01$, $* * * P<0.001$, and $n s$ non-significant. $I P C$ ischemic preconditioning 


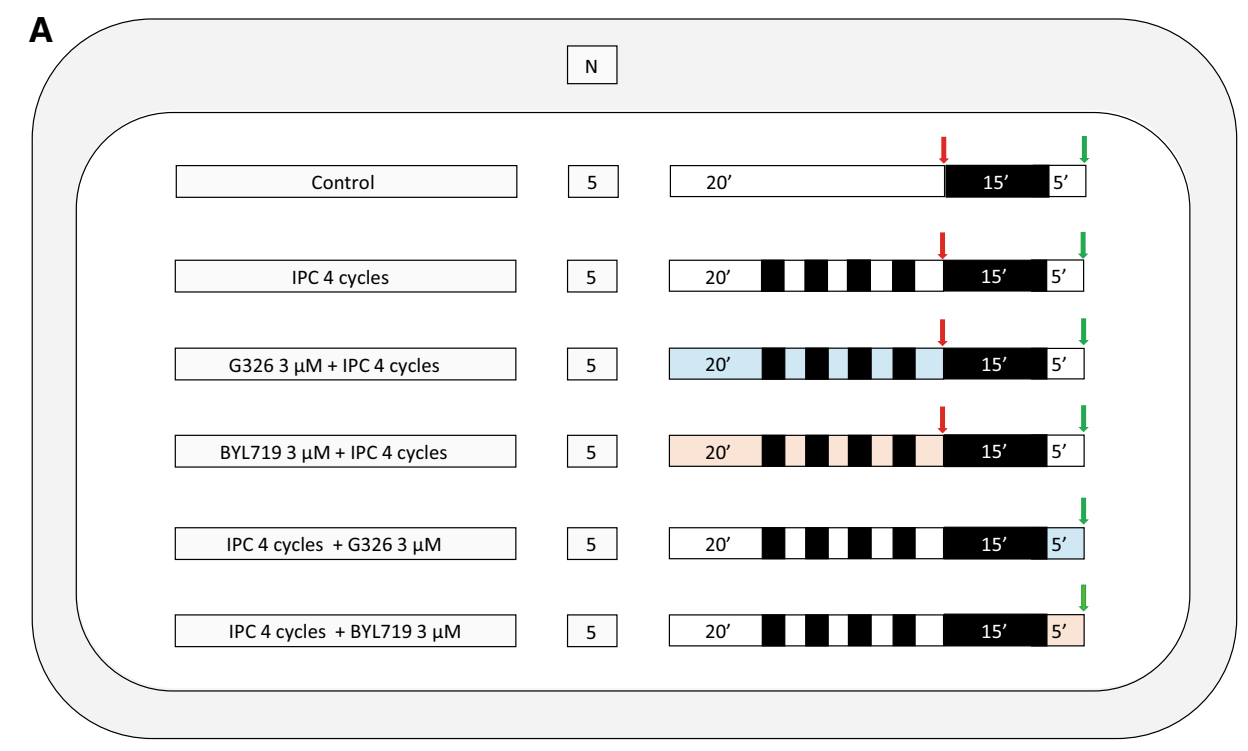

B

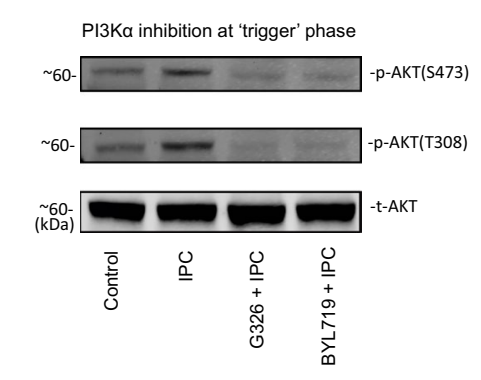

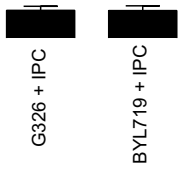

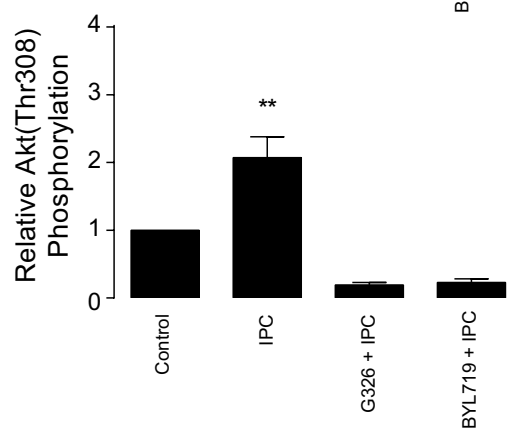

C
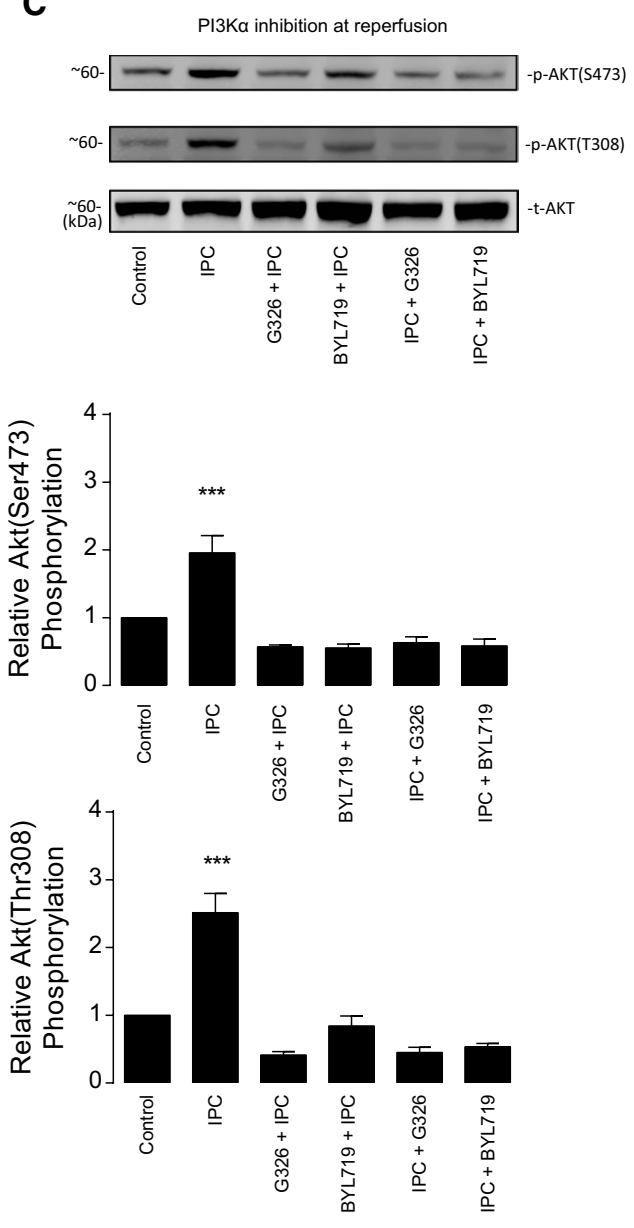

was demonstrated by showing it to be similarly expressed in both human and mouse heart tissues and to respond to insulin in both tissues. At a cellular level, PI3K $\alpha$ expression was shown to be higher in mouse cardiac endothelial cells 
4Fig. 4 Impact of PI3K $\alpha$ inhibition on Akt phosphorylation during the IPC protocol and at reperfusion. a Overview of protocols performed to assess Akt phosphorylation using western blot analysis. Black boxes represent periods of ischemia, white boxes represent periods of perfusion with Krebs-Henseleit buffer at $80 \mathrm{mmHg}$, and coloured boxes represent the perfusion of a given drug (turquoise for G326 and salmon for BYL719). Arrows represent the moment, where samples were collected (in red, all samples collected after IPC protocol; in green, all samples collected at reperfusion). b Akt activity measured after IPC in the presence or absence of PI3K $\alpha$ inhibitors (i.e., during the IPC protocol) and $\mathbf{c}$ Akt activity measured at reperfusion following PI $3 \mathrm{~K} \alpha$ inhibition during either IPC protocol phase only ("drug + IPC"), or at reperfusion ("IPC + drug"). IPC ischemic preconditioning

compared to cardiomyocytes, with its effect being mediated through the inhibition of mPTP opening.

\section{Role of PI3K $\alpha$ and other isoforms in IPC}

The RISK pathway has been widely demonstrated to be involved in the protection against IRI conferred by both mechanical and pharmacological conditioning strategies carried out at reperfusion [13, 14, 54]. PI3K is a component of this signalling cascade and, therefore, is an important therapeutic target. Nonetheless, little is known about the role of the distinct PI3K isoforms in IRI setting. Using a pharmacological approach, we have demonstrated that PI $3 \mathrm{~K} \alpha$ mediates the IPC-induced protective effect during the early moments of reperfusion, but appears not to have a role during the application of the IPC protocol. This is surprising as Akt phosphorylation was abolished at both timepoints following PI $3 \mathrm{~K} \alpha$ inhibition. Assuming that the specific-PI3K $\alpha$ inhibitors do not block other isoforms, it might be speculated that PI $3 \mathrm{~K} \alpha$-induced Akt phosphorylation is not relevant to promote myocardial salvage during the IPC protocol. The increase of PIP3 following PI3K activation by IPC would not only translate in Akt phosphorylation (which might be irrelevant in this phase) [36], but in other unrevealed cellular mechanisms.

Consistent with our results, transgenic experiments have indicated that $\mathrm{PI} 3 \mathrm{~K} \alpha$ improves left ventricular function in a mouse myocardial infarction-induced heart failure model [28], as well as improving contractile dysfunction [30, 31] and preventing exercise-induced cardiomyopathies [32].

In the heart, the most highly expressed PI3K isoforms are PI3K $\alpha$ and PI3K $\beta$ [10], although little is known about their absolute and relative amounts. PI $3 \mathrm{~K} \alpha$ can be exclusively activated by tyrosine kinase receptor, whilst there is compelling evidence demonstrating that both tyrosine kinase receptor and $\mathrm{G}$ protein-coupled receptors (GPCR) can engage $\mathrm{PI} 3 \mathrm{~K} \beta[4,11]$, which is in turn involved in Akt activation in platelets, and in thrombus formation and maintenance, but without known evidence on this involvement in IRI and cardioprotection. PI3K $\gamma$ signals downstream of GPCRs. As IPC is mostly mediated by GPCRs ligands, this PI3K isoform has raised interest in a cardiac context. Although not examined in this paper, $\mathrm{PI} 3 \mathrm{~K} \gamma$ has been postulated to be a mediator of the protection afforded by IPC, as IPC-induced protection is lost both in transgenic mice with cardiac-specific overexpression of a catalytically inactive mutant $\mathrm{PI} 3 \mathrm{~K} \gamma$ [49] and knockout mice (PI3K $\gamma^{--}$) [2]. In contrast to genetic approaches, pharmacological strategies are able to provide novel information by permitting temporally restricted inhibition during either the application of the IPC protocol or at reperfusion. Moreover, it is not always clear whether the molecular signalling alterations of genetically modified animal models can be directly attributed to the targeted gene or to the activation of compensatory signalling pathways. Taken together, we might speculate that PI3K $\gamma$, which involves GPCR-ligand activation, may be involved in the protection elicited by IPC during the IPC protocol, whilst $\mathrm{PI} 3 \mathrm{~K} \alpha$, which involves tyrosine kinase activation, is required at reperfusion for IPC to protect against IRI.

\section{Pharmacological PI3Ko activation at reperfusion}

In our study, we have used insulin as the PI $3 \mathrm{~K} \alpha$ canonical activator $[8,27]$. There is a wealth of evidence demonstrating that insulin mimics the IPC stimulus by activating the RISK pathway, therefore, conferring protection against IRI both in vitro and in vivo through the PI3K-Akt kinase cascade $[22,23,46]$. In the swine model, insulin postconditioning has recently been shown to reduce myocardial IS in a dose-dependent manner [46]. Not surprisingly, we found insulin to be protective in our models, which we confirm to specifically be mediated via PI $3 \mathrm{~K} \alpha$. Under the hypothesis of protecting the heart from energy depletion [47], insulin has already been tested as a cardioprototective therapy in the clinical setting, with overall disappointing results [34], although in the subgroup of patients presenting with STEMI in the Immediate Myocardial Metabolic Enhancement During Initial Assessment and Treatment in Emergency Care (IMMEDIATE) trial, the administration of glucose-insulin-potassium therapy significantly reduced cardiac magnetic resonance-evaluated infarct size [42]. The fact that we have identified PI $3 \mathrm{~K} \alpha$ to mediate the insulin-induced protective effect can move the focus from the use of insulin (a "dirty" drug with many side effects, such as hypoglycemia, hypokalemia, and catecholamine elevation) to the development of pharmacological agents specifically targeting PI3K $\alpha$. We are not proposing insulin to come to the fore again, but to take advantage of the overwhelming evidence demonstrating its protective effect to further improve our ability to target its downstream signalling.

With regard to the end-effector mechanism mediating the PI3K $\alpha$ effect, we used the ROS-mediated MPTP model to 


\section{PI3Ka activation at reperfusion}

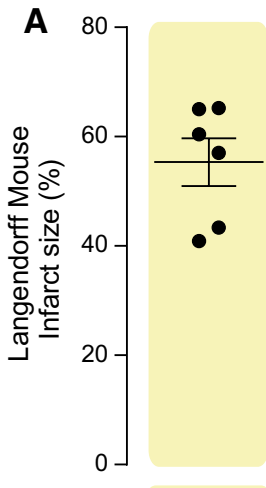

Control

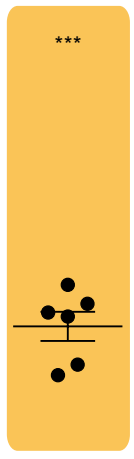

Bradykinin

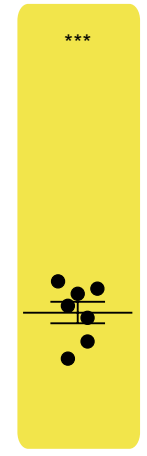

Ins

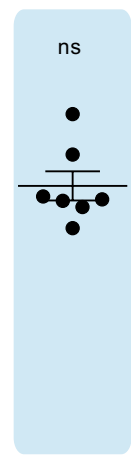

Ins + G326
B

$\sim 60$

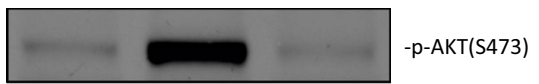

$\sim 60$

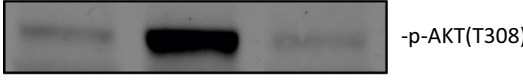

$\sim 60-$
$(\mathrm{kDa})$

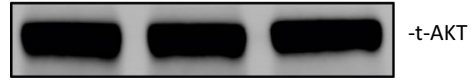

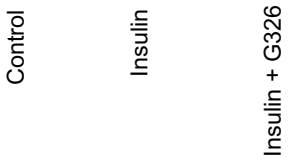

D

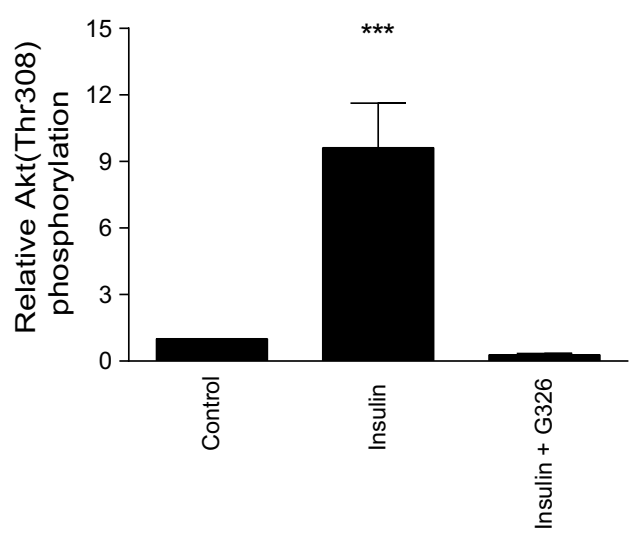

Fig. 5 Pharmacological PI3K $\alpha$ activation at reperfusion. a Effect on myocardial infarct size of PI3K $\alpha$ canonical activator (insulin) administered at reperfusion. b-d Western blot analyses. $* P<0.05$, $* * P<0.01$, $* * * P<0.001$, and $n s$ non-significant

confirm the involvement of the mitochondria in the insulin-induced PI3K $\alpha$ activation. Using broad-spectrum PI3K inhibitors, our group had previously linked the activation of the PI3K-Akt pro-survival kinase pathway through insulin with the inhibition of the MPTP [7]. Our pharmacological approach used in cells further suggests that the effect of insulin on the mPTP opening is mediated by PI3K $\alpha$, although we lack specific data linking PI $3 \mathrm{~K} \alpha$ and mPTP in preconditioned cardiomyocytes.

\section{PI3K $\alpha$ expression and activation in cells and tissues}

$\mathrm{PI} 3 \mathrm{~K} \alpha$ is expressed in a similar proportion in both mouse heart and human atrial tissue. Moreover, PI3K $\alpha$ activity can be pharmacologically modulated in both tissues, as demonstrated using its canonical activator and specific inhibitor. These observations set $\mathrm{PI} 3 \mathrm{~K} \alpha$ as a potential target with translational value in cardioprotection. To our knowledge, this is the first study reporting comparisons in $\mathrm{PI} 3 \mathrm{~K} \alpha$ protein levels between mouse and human heart tissue. Differences in protein levels between cardiomyocytes and mouse cardiac endothelial cells have also been reported, although caution should be taken when comparing primary isolated with immortalized cultured cells. Our qualitative results on PI3K $\alpha$ mRNA expression in mouse heart tissue also suggest a greater expression of the isoform in endothelial cells compared to cardiomyocytes in culture. Although cardiomyocytes have become central to recapitulate reductionist models of preconditioning against IRI through hypoxia/reoxygenation experiments, it remains largely unknown to what extent other cardiac cells can contribute in the conditioning phenomena on top of cardiomyocytes. Some advocate that the endothelium might have a relevant role in cardioprotection due to both its optimal situation to interact with blood 

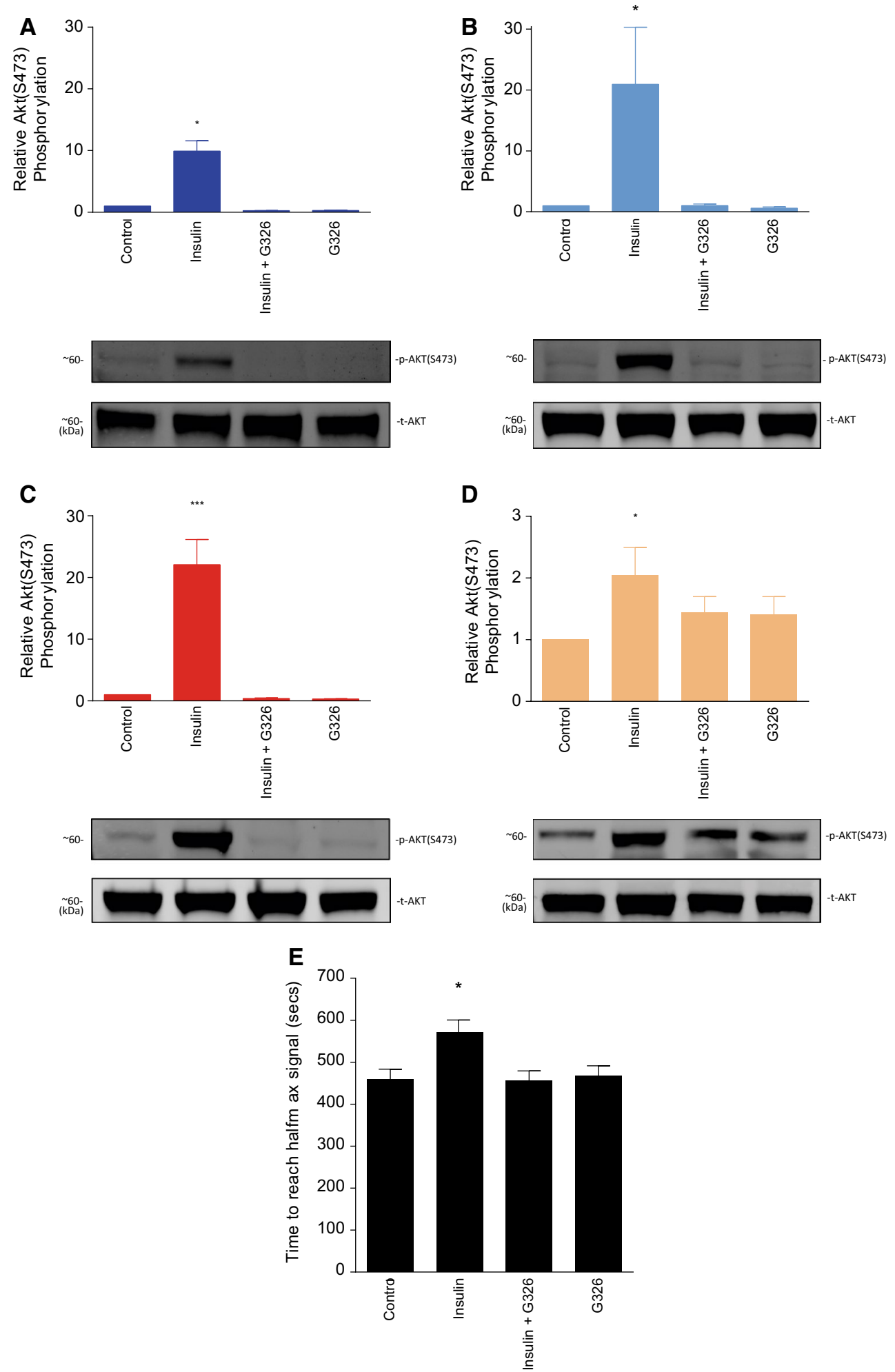

Fig. 6 Pharmacological PI $3 \mathrm{~K} \alpha$ activation in cells and tissues. Akt activation in response to treatment with insulin and the GDC-G326 inhibitor in adult mouse ventricular cardiomyocytes (a), mouse cardiac endothelial cells (b), isolated-perfused mouse heart tissue (c), and human atrial tissue (d). e ROS-stimulated mPTP opening in cardiomyocytes was de-sensitize by prior insulin treatment. $* P<0.05$, $* * P<0.01, * * * P<0.001$, and $n s$ non-significant 
Table 1 Patient baseline characteristics

\begin{tabular}{ll}
\hline & Total patients $(n=5)$ \\
\hline Age & $64.2 \pm 18.6$ \\
Gender (male) & $4(80 \%)$ \\
Diabetes mellitus & $1(20 \%)$ \\
Dyslipidemia & $2(40 \%)$ \\
Hypertension & $5(100 \%)$ \\
Smoking history & $1(20 \%)$ \\
Prior cardiovascular disease & $2(40 \%)$ \\
Preserved LVEF (> 50\%) & $4(80 \%)$ \\
Sinus rhythm & $5(100 \%)$ \\
Surgery & \\
CABG & $3(60 \%)$ \\
AVR & $1(20 \%)$ \\
CABG + AVR & $1(20 \%)$ \\
Medications & \\
Beta blocker & $4(80 \%)$ \\
ACE inhibitor & $2(40 \%)$ \\
Calcium channel blocker & $1(20 \%)$ \\
Statin & $4(80 \%)$ \\
Antiplatelet therapy & $4(80 \%)$ \\
\hline
\end{tabular}

Data expressed as number $(\%)$ or mean $\pm \mathrm{SD}$

$A V R$ aortic valve replacement, $C A B G$ coronary artery bypass graft, $L V E F$ left ventricular ejection fraction

signals and its paracrine capacity/ability, i.e., nitric oxide has been long associated with ischaemic conditioning through the role of eNOS (the endothelial isoform of nitric oxide synthase) [3]. Besides being a provider of protective triggers and mediators to cardiomyocytes, there is also the possibility for the endothelium to be a target itself for cardioprotection, i.e., preserving microvascular function. Unfortunately, there is little evidence of the specific role of PI $3 \mathrm{~K} \alpha$ to provide cardioprotection in non-cardiomyocyte cells and this issue needs to be adequately addressed in further studies.

\section{Translational outlook}

The translational perspective of our results is highlighted by the observation that PI $3 \mathrm{~K} \alpha$ is expressed in human heart tissue and can be stimulated by its canonical activator insulin, although we did not performed experiments addressing the cardioprotective effect of insulin in the human tissue. Given that PI3K $\alpha$ is involved in the cardioprotection rendered by IPC and insulin at reperfusion, future therapeutic strategies could more specifically target this $\alpha$ isoform of PI3K to enhance its IS-limiting effect in an acute post-myocardial infarction setting, and avoiding the PI3K-independent effects on the metabolism that limits the use of insulin. Thus, further studies with specific PI3K $\alpha$ activators should be tested in both small- and large-animal models, before being eventually translated in STEMI patients who undergo coronary revascularization. These studies should take into account the current challenges to translate cardioprotective therapies [17, 20, 41].

\section{Strengths and limitations}

To study the activation of the PI3K $\alpha$ isoform in IPC, we used a pharmacological approach in several experimental models (ex vivo, in vivo, and mPTP assay). Although it could be argued that genetically modified animal models could also have been used to further examine the role of PI3K $\alpha$, this would not have been possible due to the fact that chronic deletion of the protein would not allow us to focus on specific phases of the conditioning process, i.e., before ischemia and at reperfusion. To overcome the risk of off-target effects with inhibitors, we used two structurally unrelated inhibitors and observed the same results.

Human heart tissue was obtained from the right atrium. Despite carefully selecting patients without arrhythmias, we appreciate that left ventricular tissue would better represent the human model, but this was not possible to obtain. Moreover, only an insulin-dependent activation of PI3K $\alpha$ was shown in the human tissue, leaving unanswered the question on whether PI3K $\alpha$ mediates the IPC-protective effect. Caution should also be taken when extrapolating the results on an immortalized cell line (mouse cardiac endothelial cells) to a more physiological setting.

Several considerations regarding the RISK pathway need to be taken into account regarding the translational value of our results. First, most of the experimental studies involving the RISK pathway as a cardioprotective pathway have been performed in small rodent models of IRI, whereas its central role in large animals is less well established $[9,44]$. Second, we focused on classic IPC, not remote preconditioning. Whilst the link between IPC and RISK activation has been demonstrated in humans [43], there is less certainty about the role of the RISK pathway in remote preconditioning in both large-animal models [45] and humans [19].

\section{Conclusions}

$\mathrm{PI} 3 \mathrm{~K} \alpha$ activity is required during the early reperfusion phase to reduce myocardial infarct size. The development of drugs enhancing PI3K $\alpha$ activity at reperfusion could potentially promote myocardial salvage in patients undergoing acute myocardial infarction.

Acknowledgements Dr. Rossello has received support from Fundacion Rafael del Pino. Dr. Riquelme has received support from 
FONDECYT 3160298. Ms. Taferner is a recipient of a Ph.D. fellowship from the British Heart Foundation. Dr. Vanhaesebroeck is supported by Cancer Research UK (C23338/A15965) and the UK NIHR University College London Hospitals Biomedical Research Centre.

\section{Compliance with ethical standards}

Conflict of interest BV is a consultant to Karus Therapeutics (Oxford, UK). The rest of the authors declare that they have no conflict of interest.

Ethical standards All experiments were performed in The Hatter Cardiovascular Institute, University College London, in accordance with the Home Office (United Kingdom) Guidance on Research and Testing using animals and the Animals (Scientific Procedures) Act of 1986. Human atrial tissues were collected from Barts Heart Centre at St Bartholomew's Hospital. The study received Local Research Ethics Committee approval (REC No. 00/0275) and was carried out in accordance with the University College London Hospitals NHS Trust guidelines.

Informed consent All patients were provided with a Patient Information Sheet and a verbal explanation of the study, in line with Good Clinical Practice guidelines. All patients provided written informed consent and were free to participate in the Barts Cardiovascular Registry.

Open Access This article is distributed under the terms of the Creative Commons Attribution 4.0 International License (http://creativecommons.org/licenses/by/4.0/), which permits unrestricted use, distribution, and reproduction in any medium, provided you give appropriate credit to the original author(s) and the source, provide a link to the Creative Commons license, and indicate if changes were made.

\section{References}

1. Baines CP, Wang L, Cohen MV, Downey JM (1999) Myocardial protection by insulin is dependent on phospatidylinositol 3-kinase but not protein kinase C or KATP channels in the isolated rabbit heart. Basic Res Cardiol 94:188-198. doi:10.1007/ s003950050142

2. Ban K, Cooper AJ, Samuel S, Bhatti A, Patel M, Izumo S, Penninger JM, Backx PH, Oudit GY, Tsushima RG (2008) Phosphatidylinositol 3-kinase is a critical mediator of myocardial ischemic and adenosine-mediated preconditioning. Circ Res 103:643-653. doi:10.1161/CIRCRESAHA.108.175018

3. Bell RM, Yellon DM (2003) Bradykinin limits infarction when administered as an adjunct to reperfusion in mouse heart: the role of PI3K, Akt and eNOS. J Mol Cell Cardiol 35:185-193

4. Ciraolo E, Iezzi M, Marone R, Marengo S, Curcio C, Costa C, Azzolino $\mathrm{O}$, Gonella $\mathrm{C}$, Rubinetto $\mathrm{C}, \mathrm{Wu} \mathrm{H}$, Dastrù $\mathrm{W}$, Martin EL, Silengo L, Altruda F, Turco E, Lanzetti L, Musiani P, Rückle T, Rommel C, Backer JM, Forni G, Wymann MP, Hirsch E (2008) Phosphoinositide 3-kinase p110beta activity: key role in metabolism and mammary gland cancer but not development. Sci Signal 1:ra3. doi:10.1126/scisignal.1161577

5. Costa C, Ebi H, Martini M, Beausoleil SA, Faber AC, Jakubik CT, Huang A, Wang Y, Nishtala M, Hall B, Rikova K, Zhao J, Hirsch E, Benes CH, Engelman JA (2015) Measurement of PIP3 levels reveals an unexpected role for $\mathrm{p} 110 \beta$ in early adaptive responses to $\mathrm{p} 110 \alpha$-specific inhibitors in luminal breast cancer. Cancer Cell 27:97-108. doi:10.1016/j.ccell.2014.11.007
6. Crompton M (1999) The mitochondrial permeability transition pore and its role in cell death. Biochem J 341:233-249. doi:10.1042/bj3410233

7. Davidson SM, Hausenloy D, Duchen MR, Yellon DM (2006) Signalling via the reperfusion injury signalling kinase (RISK) pathway links closure of the mitochondrial permeability transition pore to cardioprotection. Int J Biochem Cell Biol 38:414 419. doi:10.1016/j.biocel.2005.09.017

8. Foukas LC, Claret M, Pearce W, Okkenhaug K, Meek S, Peskett E, Sancho S, Smith AJH, Withers DJ, Vanhaesebroeck B (2006) Critical role for the p110alpha phosphoinositide-3-OH kinase in growth and metabolic regulation. Nature 441:366-370. doi:10.1038/nature04694

9. Gent S, Skyschally A, Kleinbongard P, Heusch G (2017) lschemic preconditioning in pigs: a causal role for signal transducer and activator of transcription 3. Am J Physiol Heart Circ Physiol 312:H478-H484. doi:10.1152/ajpheart.00749.2016

10. Ghigo A, Morello F, Perino A, Damilano F, Hirsch E (2011) Specific PI3K isoform modulation in heart failure: lessons from transgenic mice. Curr Heart Fail Rep 8:168-175. doi:10.1007/ s11897-011-0059-3

11. Guillermet-Guibert J, Bjorklof K, Salpekar A, Gonella C, Ramadani F, Bilancio A, Meek S, Smith AJH, Okkenhaug K, Vanhaesebroeck B (2008) The p110beta isoform of phosphoinositide 3-kinase signals downstream of $\mathrm{G}$ protein-coupled receptors and is functionally redundant with p110gamma. Proc Natl Acad Sci USA 105:8292-8297. doi:10.1073/ pnas.0707761105

12. Hausenloy DJ, Mocanu MM, Yellon DM (2004) Cross-talk between the survival kinases during early reperfusion: its contribution to ischemic preconditioning. Cardiovasc Res 63:305-312. doi:10.1016/j.cardiores.2004.04.011

13. Hausenloy DJ, Yellon DM (2007) Preconditioning and postconditioning: united at reperfusion. Pharmacol Ther 116:173-191. doi:10.1016/j.pharmthera.2007.06.005

14. Hausenloy DJ, Yellon DM (2007) Reperfusion injury salvage kinase signalling: taking a RISK for cardioprotection. Heart Fail Rev 12:217-234. doi:10.1007/s10741-007-9026-1

15. Heffron TP, Heald RA, Ndubaku C, Wei B, Augistin M, Do S, Edgar K, Eigenbrot C, Friedman L, Gancia E, Jackson PS, Jones G, Kolesnikov A, Lee LB, Lesnick JD, Lewis C, McLean N, Mörtl M, Nonomiya J, Pang J, Price S, Prior WW, Salphati L, Sideris S, Staben ST, Steinbacher S, Tsui V, Wallin J, Sampath D, Olivero AG (2016) The rational design of selective benzoxazepin inhibitors of the $\alpha$-isoform of phosphoinositide 3-kinase culminating in the identification of $(S)-2-((2-(1-i s o p r o p y l-1 H-1,2,4-$ triazol-5-yl)5,6-dihydrobenzo[f]imidazo[1,2-d][1, 4]oxazepin-9-yl)oxy)propanamide (GDC-0326). J Med Chem 59:985-1002. doi:10.1021/ acs.jmedchem. 5 b01483

16. Heusch G (2015) Molecular basis of cardioprotection: signal transduction in ischemic pre-, post-, and remote conditioning. Circ Res 116:674-699. doi:10.1161/CIRCRESAHA.116.305348

17. Heusch $G$ (2017) Critical issues for the translation of cardioprotection. Circ Res 120:1477-1486. doi:10.1161/ CIRCRESAHA.117.310820

18. Heusch G, Bøtker HE, Przyklenk K, Redington A, Yellon D (2015) Remote ischemic conditioning. J Am Coll Cardiol 65:177195. doi:10.1016/j.jacc.2014.10.031

19. Heusch G, Musiolik J, Kottenberg E, Peters J, Jakob H, Thielmann M (2012) STAT5 activation and cardioprotection by remote ischemic preconditioning in humans. Novelty and significance. Circ Res 110:111-115. doi:10.1161/CIRCRESAHA.111.259556

20. Heusch G, Rassaf T (2016) Time to give up on cardioprotection? A critical appraisal of clinical studies on ischemic pre-, post-, and remote conditioning. Circ Res 119:676-695. doi:10.1161/ CIRCRESAHA.116.308736 
21. Jia S, Liu Z, Zhang S, Liu P, Zhang L, Lee SH, Zhang J, Signoretti S, Loda M, Roberts TM, Zhao JJ (2008) Essential roles of PI(3) K-p110beta in cell growth, metabolism and tumorigenesis. Nature 454:776-779. doi:10.1038/nature07091

22. Jonassen AK, Brar BK, Mjøs OD, Sack MN, Latchman DS, Yellon DM (2000) Insulin administered at reoxygenation exerts a cardioprotective effect in myocytes by a possible anti-apoptotic mechanism. J Mol Cell Cardiol 32:757-764. doi:10.1006/ jmcc. 2000.1118

23. Jonassen AK, Sack MN, Mjøs OD, Yellon DM (2001) Myocardial protection by insulin at reperfusion requires early administration and is mediated via Akt and p70s6 kinase cell-survival signaling. Circ Res 89:1191-1198. doi:10.1161/hh2401.101385

24. Kilkenny C, Browne WJ, Cuthill IC, Emerson M, Altman DG (2010) Improving bioscience research reporting: the ARRIVE guidelines for reporting animal research. PLoS Biol 8:e1000412. doi:10.1371/journal.pbio.1000412

25. Klein HH, Puschmann S, Schaper J, Schaper W (1981) The mechanism of the tetrazolium reaction in identifying experimental myocardial infarction. Virch Arch 393:287-297

26. Kleinbongard P, Heusch G (2015) Extracellular signalling molecules in the ischaemic/reperfused heart-druggable and translatable for cardioprotection? Br J Pharmacol 172:2010-2025. doi:10.1111/bph.12902

27. Knight ZA, Gonzalez B, Feldman ME, Zunder ER, Goldenberg DD, Williams O, Loewith R, Stokoe D, Balla A, Toth B, Balla T, Weiss WA, Williams RL, Shokat KM (2006) A pharmacological map of the PI3-K family defines a role for $\mathrm{p} 110$ ? in insulin signaling. Cell 125:733-747. doi:10.1016/j.cell.2006.03.035

28. Lin RCY, Weeks KL, Gao XM, Williams RBH, Bernardo BC, Kiriazis H, Matthews VB, Woodcock EA, Bouwman RD, Mollica JP, Speirs HJ, Dawes IW, Daly RJ, Shioi T, Izumo S, Febbraio MA, Du XJ, McMullen JR (2010) PI3K(p110) protects against myocardial infarction-induced heart failure: identification of PI3K-regulated miRNA and mRNA. Arterioscler Thromb Vasc Biol 30:724-732. doi:10.1161/ATVBAHA.109.201988

29. Lu M-J, Chen Y-S, Huang H-S, Ma M-C (2014) Hypoxic preconditioning protects rat hearts against ischemia-reperfusion injury via the arachidonate12-lipoxygenase/transient receptor potential vanilloid 1 pathway. Basic Res Cardiol 109:414. doi:10.1007/ s00395-014-0414-0

30. Lu Z, Jiang Y-P, Wang W, Xu X-H, Mathias RT, Entcheva E, Ballou LM, Cohen IS, Lin RZ (2009) Loss of cardiac phosphoinositide 3-kinase p110 alpha results in contractile dysfunction. Circulation 120:318-325. doi:10.1161/ CIRCULATIONAHA.109.873380

31. McLean BA, Zhabyeyev P, Patel VB, Basu R, Parajuli N, DesAulniers J, Murray AG, Kassiri Z, Vanhaesebroeck B, Oudit GY (2015) PI $3 \mathrm{~K} \alpha$ is essential for the recovery from Cre/tamoxifen cardiotoxicity and in myocardial insulin signalling but is not required for normal myocardial contractility in the adult heart. Cardiovasc Res 105:292-303. doi:10.1093/cvr/cvv016

32. McMullen JR, Amirahmadi F, Woodcock EA, Schinke-Braun M, Bouwman RD, Hewitt KA, Mollica JP, Zhang L, Zhang Y, Shioi T, Buerger A, Izumo S, Jay PY, Jennings GL (2007) Protective effects of exercise and phosphoinositide 3-kinase(p110) signaling in dilated and hypertrophic cardiomyopathy. Proc Natl Acad Sci 104:612-617. doi:10.1073/pnas.0606663104

33. McMullen JR, Shioi T, Zhang L, Tarnavski O, Sherwood MC, Kang PM, Izumo S (2003) Phosphoinositide 3-kinase(p110alpha) plays a critical role for the induction of physiological, but not pathological, cardiac hypertrophy. Proc Natl Acad Sci USA 100:12355-12360. doi:10.1073/pnas.1934654100

34. Mehta SR, Yusuf S, Díaz R, Zhu J, Pais P, Xavier D, Paolasso E, Ahmed R, Xie C, Kazmi K, Tai J, Orlandini A, Pogue J, Liu L (2005) Effect of glucose-insulin-potassium infusion on mortality in patients with acute ST-segment elevation myocardial infarction: the CREATE-ECLA randomized controlled trial. JAMA 293:437-446. doi:10.1001/jama.293.4.437

35. Murry CE, Jennings RB, Reimer KA (1986) Preconditioning with ischemia: a delay of lethal cell injury in ischemic myocardium. Circulation 74:1124-1136. doi:10.1161/01.CIR.74.5.1124

36. Oudit GY, Penninger JM (2009) Cardiac regulation by phosphoinositide 3-kinases and PTEN. Cardiovasc Res 82:250-260. doi:10.1093/cvr/cvp014

37. Pretorius L, Du X-J, Woodcock EA, Kiriazis H, Lin RCY, Marasco S, Medcalf RL, Ming Z, Head GA, Tan JW, Cemerlang N, Sadoshima J, Shioi T, Izumo S, Lukoshkova EV, Dart AM, Jennings GL, McMullen JR (2009) Reduced phosphoinositide 3-kinase (p110alpha) activation increases the susceptibility to atrial fibrillation. Am J Pathol 175:998-1009. doi:10.2353/ ajpath.2009.090126

38. Rossello X, Burke N, Stoppe C, Bernhagen J, Davidson SM, Yellon DM (2016) Exogenous administration of recombinant MIF at physiological concentrations failed to attenuate infarct size in a Langendorff perfused isolated mouse heart model. Cardiovasc Drugs Ther 30:445-453. doi:10.1007/s10557-016-6673-2

39. Rossello X, Hall AR, Bell RM, Yellon DM (2015) Characterization of the Langendorff perfused isolated mouse heart model of global ischemia-reperfusion injury: impact of ischemia and reperfusion length on infarct size and LDH release. J Cardiovasc Pharmacol Ther 21:286-295. doi:10.1177/1074248415604462

40. Rossello X, Riquelme JA, Davidson SM, Yellon DM (2017) Role of PI3K in myocardial ischaemic preconditioning: mapping prosurvival cascades at the trigger phase and at reperfusion. J Cell Mol Med. doi:10.1111/jcmm.13394

41. Rossello X, Yellon DM (2016) Cardioprotection: the disconnect between bench and bedside. Circulation 134:574-575. doi:10.1161/CIRCULATIONAHA.116.022829

42. Selker HP, Beshansky JR, Sheehan PR, Massaro JM, Griffith JL, D'Agostino RB, Ruthazer R, Atkins JM, Sayah AJ, Levy MK, Richards ME, Aufderheide TP, Braude DA, Pirrallo RG, Doyle DD, Frascone RJ, Kosiak DJ, Leaming JM, Van Gelder CM, Walter G-P, Wayne MA, Woolard RH, Opie LH, Rackley CE, Apstein CS, Udelson JE (2012) Out-of-hospital administration of intravenous glucose-insulin-potassium in patients with suspected acute coronary syndromes: the IMMEDIATE randomized controlled trial. JAMA 307:1925-1933. doi:10.1001/jama.2012.426

43. Sivaraman V, Hausenloy DJ, Wynne AM, Yellon DM (2010) Preconditioning the diabetic human myocardium. J Cell Mol Med 14:1740-1746. doi:10.1111/j.1582-4934.2009.00796.x

44. Skyschally A, van Caster P, Boengler K, Gres P, Musiolik J, Schilawa D, Schulz R, Heusch G (2009) Ischemic postconditioning in pigs: no causal role for RISK activation. Circ Res 104:15-18. doi:10.1161/CIRCRESAHA.108.186429

45. Skyschally A, Gent $S$, Amanakis G, Schulte C, Kleinbongard P, Heusch G (2015) Across-species transfer of protection by remote ischemic preconditioning with species-specific myocardial signal transduction by reperfusion injury salvage kinase and survival activating factor enhancement pathways. Novelty and significance. Circ Res 117:279-288. doi:10.1161/CIRCRESAHA.117.306878

46. Slettom G, Jonassen AK, Dahle GO, Seifert R, Larsen TH, Berge RK, Nordrehaug JE (2017) Insulin postconditioning reduces infarct size in the porcine heart in a dose-dependent manner. J Cardiovasc Pharmacol Ther 22:179-188. doi:10.1177/1074248416657611

47. Sodi-Pallares D, Testelli MR, Fishleder BL, Bisteni A, Medrano GA, Friedland C, De Micheli A (1962) Effects of an intravenous infusion of a potassium-glucose-insulin solution on the electrocardiographic signs of myocardial infarction. A preliminary clinical report. Am J Cardiol 9:166-181. doi:10.1016/0002-9149(62)90035-8 
48. Soler A, Figueiredo AM, Castel P, Martin L, Monelli E, AnguloUrarte A, Milà-Guasch M, Viñals F, Baselga J, Casanovas O, Graupera M (2016) Therapeutic benefit of selective inhibition of p110 $\alpha$ PI3-kinase in pancreatic neuroendocrine tumors. Clin Cancer Res 22:5805-5817. doi:10.1158/1078-0432.CCR-15-3051

49. Tong H, Rockman HA, Koch WJ, Steenbergen C, Murphy E (2004) G protein-coupled receptor internalization signaling is required for cardioprotection in ischemic preconditioning. Circ Res 94:1133-1141. doi:10.1161/01.RES.0000126048.32383.6B

50. Vanhaesebroeck B, Ali K, Bilancio A, Geering B, Foukas LC (2005) Signalling by PI3K isoforms: insights from gene-targeted mice. Trends Biochem Sci 30:194-204. doi:10.1016/j. tibs.2005.02.008
51. Vanhaesebroeck B, Whitehead MA, Piñeiro R (2016) Molecules in medicine mini-review: isoforms of PI3K in biology and disease. J Mol Med (Berl) 94:5-11. doi:10.1007/s00109-015-1352-5

52. Yano N, Tseng A, Zhao TC, Robbins J, Padbury JF, Tseng Y-T (2008) Temporally controlled overexpression of cardiac-specific PI3Kalpha induces enhanced myocardial contractility-a new transgenic model. AJP Hear Circ Physiol 295:H1690-H1694. doi:10.1152/ajpheart.00531.2008

53. Yellon DM, Alkhulaifi AM, Pugsley WB (1993) Preconditioning the human myocardium. Lancet 342:276-277. doi:10.1016/0140-6736(93)91819-8

54. Yellon DM, Hausenloy DJ (2007) Myocardial reperfusion injury. N Engl J Med 357:1121-1135. doi:10.1056/NEJMra071667 